участия должника по основному обязательству, без его уведомления, но и вопреки его воле.

$$
* * *
$$

1. Гражданский Кодекс Российской Федерации. Часть первая: Федеральный закон от 30.11.1994 № 51-Ф3 // Собр. законодательства РФ. 1994. № 32. Ст. 3301.

2. О некоторых вопросах разрешения споров, связанных с поручительством: Постановление Пленума ВАС РФ от 12.07.2012 г. № 42 [Электронный ресурс] // КонсультантПлюс: справ. правовая система.

3. Петрова Н.Ф. Участие должника в договоре поручительства // Журнал российского права. 2009. № 4.

4. Кудрявцева Л.В., Давидан П.С. Проблемы правового регулирования договорных и иных правоотношений в агропромышленном комплексе // Бюллетень науки и практики. 2018. Т. 4. № 11. C. 411-415.

5. Kudryavtseva L.V., Stavilo S.P., Ofisov V.V., Kachur A.N. DIRECTIONS OF IMPROVING CIVIL LAW RELATIONS IN LAND USE // Mediterranean Journal of Social Sciences. 2015. T. 6. № 3 S3. C. $115-122$.

\title{
Филимонова В.А. К вопросу о бесплатной юридической помощи
}

Кубанский государственный аграрный университет им. И. Т. Трубилина (Россия, Краснодар)

doi: $10.18411 / \mathrm{j}-06-2021-251$

\section{Аннотация}

Потребность в получении юридической помощи возникает регулярно и повсеместно. Де-факто нет такой сферы в жизни или деятельности человека, в которой не нужно было бы быть осведомленным в каких-либо правовых нормах или уметь их грамотно применять. В связи с этой уже повседневной потребностью необходима определенная система защиты прав и свобод лиц, которые нуждаются в квалифицированной помощи, с учетом их финансового положения, ведь нельзя упускать из виду население, которые находятся в черте бедности. По этой причине в РФ был взят курс на построение правового государства, способного обеспечить возможность для всех получить квалифицированную юридическую помощь, что и закреплено в Конституции Российской Федерации. По этой причине предоставляемая статья посвящена раскрытию актуальных вопросов реализации конституционного права на бесплатную юридическую помощь, которое также получило свою огласку в Федеральном законе от 21 ноября 2012 года «О бесплатной юридической помощи».

Ключевые слова: система бесплатной юридической помощи, юридическая клиника, конституционное право, участники системы юридической помощи, квалифицированная юридическая помощь.

\section{Abstract}

The need for legal assistance arises regularly and everywhere. De facto, there is no sphere in the life or activity of a person in which it would not be necessary to be aware of any legal norms or be able to apply them competently. In connection with this already daily need, a certain system of protection of the rights and freedoms of persons who need qualified assistance, taking into account their financial situation, is necessary, because it is impossible to lose sight of the population who are in the poverty line. For this reason, the Russian Federation has taken a course to build a state of law that can provide an opportunity for everyone to receive qualified legal assistance, which is enshrined in the Constitution of the Russian Federation. For this reason, the article is devoted to the disclosure of topical issues of 
the implementation of the constitutional right to free legal assistance, which also received its publicity in the Federal Law of November 21, 2012 "On Free Legal Assistance".

Keywords: free legal aid system, legal clinic, constitutional law, participants in the legal aid system, qualified legal aid.

Конституцией Российской Федерации установлено, что человек с его правами и свободами является высшей ценностью, а обеспечение этого правила является обязанностью государства и обеспечивается правосудием. Таким образом, гарантируя государственную защиту прав и свобод всех на условиях конъюнктуры, государство предоставляет населению возможность защиты своих прав и свобод всеми способами, которые не запрещены российским законодательством. В связи с этим заведомо становится понятно, что в полной мере обычный человек, в нашем случае это без должного юридического образования, полностью не способен обеспечить данное право. Данную диллему можно проследить, например, в замешательстве человека о том, какой компетентный орган способен защитить то или иное нарушенное право. Зачастую многие лица, которые не имеют специальных знаний в сфере юриспруденции не могут автономно реализовать свои законные права и интересы вследствие того, что не осведомлены об этих правах, не могут правильно истолковать или применить ту или иную правовую норму и должным образом оформить документ правового характера. Приведенные примеры наглядно показывают, что без помощи квалифицированного юриста лицо не сможет во всей полноте реализовывать и защищать свои признанные права и интересы. В связи с этим высшим законном Российской Федерации в части 1 , статьи 48 предусмотрен механизм возможных мероприятий, которые направлены на защиту прав и законных интересов лиц. Условленная система мероприятий и называется юридическая помощь.

Обеспечение квалифицированной юридической помощью всех, нуждающихся в ней, является важнейшим конституционным положением. Это является очень важным и значительным элементом конституционного положения, так как он направлен на справедливое проживание на территории России, с возможностью не только о знании своих прав, но и возможностью их реализации и защиты, а также повышения социальной защищенности и обеспечения доступа к правосудию. Подводя к теме нашей научной статьи, отметим, что законодательство позаботилось и о людях, которые находятся в пределах черты бедности и не могут иметь возможности оплачивать юридические услуги. В Конституции РФ отмечено, что предусматриваются случаи, когда юридическая помощь может оказываться бесплатно. Беря во внимание в целом предоставленную конституционную гарантию, право на ее реализацию не было должным образом предоставлено. По этой причине 12 ноября 2011 года был принят Федеральный закон №324-Ф3 "О бесплатной юридической помощи в Российской Федерации". В приведенном законе нет общего понимания бесплатной юридической помощи, что приводит к определенным сложностям в процессе реализации прав граждан. На мой взгляд, важным аспектом в данном случае является неурегулированная процедура отнесения лиц к категории, имеющей право на получение бесплатной юридической помощи. По этой причине приходится больше времени тратить на определение таких лиц, запрашивать соответствующие документы на определение их статуса. Какие же все-таки категории граждан имеют право на предоставления им бесплатной системы мероприятий по защите своих прав? Ответ на этот вопрос можно найти в части 1 , статьи 20 Ф3 «О бесплатной юридической помощи в РФ», где рассмотрены категории и случаи ее оказания. Приведем примеры некоторых из них:

1) граждане, среднедушевой доход семей которых ниже величины прожиточного минимума, установленного в субъекте Российской Федерации в соответствии с законодательством Российской Федерации, 
либо одиноко проживающие граждане, доходы которых ниже величины прожиточного минимума (далее - малоимущие граждане);

2) инвалиды I и II группы;

3) ветераны Великой Отечественной войны, Герои Российской Федерации, Герои Советского Союза, Герои Социалистического Труда, Герои Труда Российской Федерации;

4) дети-инвалиды, дети-сироты, дети, оставшиеся без попечения родителей, лица из числа детей-сирот и детей, оставшихся без попечения родителей, а также их законные представители и представители, если они обращаются за оказанием бесплатной юридической помощи по вопросам, связанным с обеспечением и защитой прав и законных интересов таких детей;

5) граждане пожилого возраста и инвалиды, проживающие в организациях социального обслуживания, предоставляющих социальные услуги в стационарной форме;

Не очень благоразумным является предъявление минимальных требований к лицам, которые оказывают бесплатную юридическую помощь, среди которых достаточным и основным считается наличие высшего юридического образования. По моему мнению, помощь должна быть не только бесплатной, но и качественной, ведь тогда становится неясным вопрос о смысле существования данной системы, если она неэффективна в действии. Разобравшись с требования к лицам, оказывающих бесплатную юридическую помощь, затронем и субъектов данной системы. Лицами, оказывающими бесплатную юридическую помощь, являются физические и юридические лица, которые являются участниками государственной и негосударственной систем бесплатной юридической помощи, а также иные лица, имеющие на это право. Участниками государственной системы по этому вопросу выступают федеральные органы исполнительной власти и подведомственные им Федеральный закон от 21.11.2011 N 324-Ф3 (ред. от 26.07.2019) "О бесплатной юридической помощи в Российской Федерации", статья учреждения; органы исполнительной власти субъектов Российской Федерации и подведомственные им учреждения, органы управления государственных внебюджетных фондов, государственные юридические бюро. Хочется сказать, что деятельность адвоката - это, прежде всего, квалифицированная юридическая помощь, выражающаяся в участие в различных типах процессуальных действий, а так же в подготовке юридической документации, в разъяснение различных вопросов и т.д. Важность данной профессии неоспорима, ведь право на оказание квалифицированной юридической помощи имеют все. Процессуальные действия заключаются в непосредственных действиях представителя по определенному делу от имени и в интересах представляемого, которые порождают конкретные процессуальные права и обязанности у представляемого.Также следует отметить, что адвокаты, нотариусы и другие лица, которые участвуют в оказании бесплатной юридической помощи, могут быть наделены правом на участие в государственной системе, касающейся вопроса об оказании бесплатной юридической помощи. Интересно то, что негосударственная система оказания данной услуги бесплатно строится на добровольных началах. К такому неожиданному обстоятельству закон относит юридические клиники, в которых студенты оказывают безвозмездную юридическую помощь гражданам, в связи с чем это позволяет подготовить будущих профессионалом в области юриспруденции, посредством выработки профессиональных навыков и опыта работы с клиентами, а гражданам в свою очередь это оказывает помощь в решении юридических вопросов, возникших в силу недостатка достоверных знаний в правовой сфере. Юридические клиники могут оказывать бесплатную юридическую помощь только в двух формах: 
1. Правовое консультирование, которое может быть предоставлено как в устной, так и в письменной форме;

2. Составление каких-либо правовых документов, например, жалоб, заявлений, ходатайств

Становится довольна очевидна одна проблема, которая тесно связана с таким явлением как юридическая клиника. В силу обстоятельств участники юридической клиники не могут предоставлять и защищать интересы граждан в суде, государственных и муниципальных органов и организаций. Таким образом, вопрос об оказании бесплатной юридической помощи остается по-прежнему слабо урегулированным, потому тема совершенствования данной системы не теряет своей актуальности, и одним из этих направлений я вижу непосредственное внесение поправок в Федеральный закон №324. Стоит отметить, что на минюста РФ и подведомственных ему учреждениях возлагается непосредственное обеспечение и контроль за организацией оказания бесплатной юридической помощи. И уже в 2020 году Министерство Юстиции Российской Федерации заявили о готовящихся поправках в условленный ФЗ.

Подводя итог, хочется в очередной раз отметить, что конституционной гарантией является не сам факт наличия возможности получения бесплатной юридической помощи, но и ее качественное и квалифицированное исполнение.

$$
* * *
$$

1. Бондарь О.Н. Квалифицированная юридическая помощь - конституционная гарантия судебной защиты прав и свобод человека и гражданина в РФ: автореф. дис. ... канд. юрид. наук. Ростов-наДону, 2008.

2. Ботнев В.К. Квалифицированная юридическая помощь как конституционно-правовая гарантия защиты прав и свобод человека и гражданина: автореферат дис. ... докт. юрид. наук. Москва, 2013

3. Гринь Е.А., Батлукова А.Д. Адвокатская этика - основа деятельности адвоката // В сборнике: Поколение будущего. сборник избранных статей Международной студенческой научной конференции. Санкт-Петербург, 2020. С. 97-99.

4. $\quad$ Гринь Е.А., Градинар Э.В. О судебном (процессуальном) представительстве и представительстве по назначению суда // Аграрное и земельное право. 2020. № 9 (189). С. 129-132.

5. Кручинин Ю.С., Арапов В.В. Вопросы реализации государственной системы бесплатной юридической помощи в Российской Федерации // Адвокат. - 2012. - № 12. С. 5-12./Справочноправовая система «Консультант Плюс»

6. О бесплатной юридической помощи в Российской Федерации : федеральный закон от 21 ноября 2011 г. № 324 - Ф3 // Официальный интернет-портал правовой информации www.pravo.gov.ru.

7. Плетень А.С. Конституционное право на бесплатную юридическую помощь и механизм его реализации в современной России: автореферат дис. ... кандидата юридических наук. - М., 2008

8. Пресняков М.В., Васильев А.А. Получатели бесплатной юридической помощи в Российской Федерации // Закон. - 2012. - № 11. - С. 63 - 71// Справочно-правовая система «Консультант Плюс»

\section{Шереметьева Н.В. \\ Ограниченные вещные права на примере зарубежных стран}

Владивостокский государственный университет экономики и сервиса (Россия, Владивосток)

doi: $10.18411 / \mathrm{j}-06-2021-252$

\section{Аннотация}

Работа посвящена зарубежному правовому регулированию ограниченных вещных прав. Рассматриваются особенности ограниченных вещных прав во Франции, Германии, США.

Ключевые слова: залог, ипотека, ограниченные вещные права, сервитут, узус, узуфрукт. 